\title{
Understanding livestock production and sustainability of grassland ecosystems in the Asian Dryland Belt
}

\author{
Jiaguo Qi ${ }^{1,4^{*}} \mathbb{D}$, Xiaoping Xin², Ranjeet John ${ }^{1}$, Pavel Groisman ${ }^{3}$ and Jiquan Chen ${ }^{1}$
}

\begin{abstract}
Background: Companioned by economic development, a dietary shift toward higher meat consumption is seen in developing countries and transitional economies, where the demand for livestock production has been increasing in response to such a dietary shift. In the Asian Dryland Belt, approaches to meet this demand have focused on grazing intensification, cropland conversion for animal feed, and supplemental feeding. With the scarcity of water, energy, and food in the region, a key question is whether or not the current approaches are sustainable. If not, what are the pathways to increase livestock production while protecting the region's environment for a sustainable future? We provide our reviews and discuss current approaches in response to these dietary shifts and assess their environmental resilience with a focus on the grassland ecosystems in the Asian Dryland Belt.

Results: While current approaches alleviate the urgent need for short-term livestock production, they lead to longterm vulnerability in food security. Trade-offs between short gains and long-term losses, between food for humans and for animals, and between agricultural intensification and environmental degradation need to be holistically examined for the sustainable development of the region. A grassland water, energy, and food nexus framework is proposed with specific recommendations to increase livestock production while considering other ecosystem services of the dryland grassland ecosystems in the Asian Dryland Belt.

Conclusions: Current practices to increase livestock production are likely to lead to long-term, large-scale ecological degradation of the grassland ecosystems in the Asian Dryland Belt and are thus unsustainable. By considering the trade-offs in the nexus of water, land, food, and livelihoods, sustainable pathways were articulated and recommended. Future pilot studies are needed for validation and adoption.
\end{abstract}

Keywords: Dietary shift, Livestock production, Sustainability, Grassland, WEF nexus, Drylands

\section{Review} Introduction

There is no question that we must produce an additional $70 \%$ of food to feed the estimated 2.2 billion additional people on the planet by 2050 (FAO 2009). The demand for the additional food lies not only in meeting the basic resources needed to sustain a healthy lifestyle but also in changing diets (Fig. 1). It is forecasted that the global demand for meat will amount to 0.2 billion tons per year

\footnotetext{
* Correspondence: qi@msu.edu

${ }^{1}$ Department of Geography, Environment, and Spatial Sciences and Center for Global Change and Earth Observations, Michigan State University, East Lansing, MI, USA

${ }^{4}$ Zhejiang University, Hangzhou, China

Full list of author information is available at the end of the article
}

by 2050-approximately double the present meat consumption due to population growth and dietary changes (Tilman et al. 2011; Flammini et al. 2014; Sans and Combris 2015). The rapid changes in dietary and consumption behaviors heighten the demand for livestock production around the world (Gerbens-Leenes et al. 2010; Godfray et al. 2010; Rask and Rask 2011), but even more so in the developing countries (Fig. 1), according to FAO statistics (FAO 2013).

It is noticeable that current meat consumption is quite low per capita per year in developing countries at an average $20 \mathrm{~kg} / \mathrm{capita} /$ year in comparison with the 80 $100 \mathrm{~kg} / \mathrm{capita} /$ year in developed countries. This suggests that as these countries transition toward development, the demand for meat will rapidly increase (Delgado 


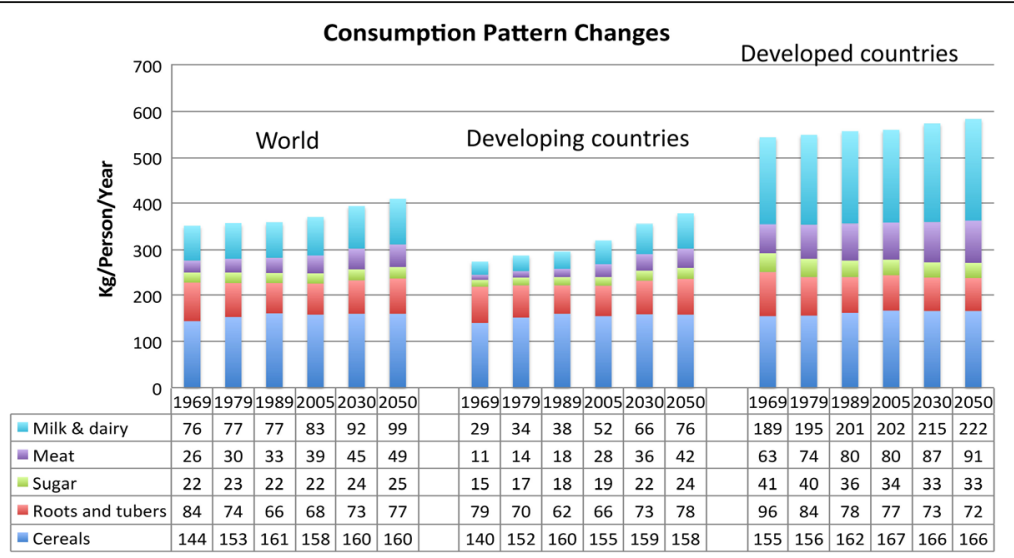

Fig. 1 Increasing consumption of meat and milk in developed and developing countries based on the statistics of FAO (2013)

2003; Sans and Combris 2015). By 2030, it is estimated that the total demand of meat will be about $109 \times 10^{9} \mathrm{~kg}$ (Robinson and Pozzi 2011; Alexandratos and Bruinsma 2012; FAO 2013). To meet this demand, meat production has to increase by $27 \%$ in comparison with the amount consumed in 2005 according to FAO statistics (Alexandratos and Bruinsma 2012; FAO 2013).

Recent studies show that some developing countries have shifted from cereal dominated diets to meat in recent decades following increased urbanization and economic growth (Delgado 2003; Ndambi et al. 2007; Sahadeo and Zanca 2007; Bosire et al. 2015, 2017). For example, meat production in China increased by $24 \%$ from 2005 to 2014, as a result of dietary shifts and increased household wealth (Delgado 2003, 2005; Alexandratos and Bruinsma 2012; Sans and Combris 2015). With continuous economic development and urbanization, demand for meat production will also continuously increase, mounting pressures to produce more livestock; however, arable lands remain limited for feed production. In response to this demand, the grassland ecosystems in the Asian Dryland Belt (ADB) remain intensively used for grazing or feedstock production due to the needs for maintaining the livestock (Chuluun and Ojima 2002; McMichael et al. 2007; Godfray et al. 2010; Lemaire et al. 2014).

Given these demands to increase livestock production, a series of questions during land use change may include the following: What are the current approaches to increase livestock production in the ADB? Are they sustainable in the long run? If not, what are the sustainable pathways to meet these demanding challenges while sustainably using limited natural resources and protecting the environment in the region? Our objectives in this paper are to review current approaches in response to these dietary demands, assess their environmental consequences, and propose alternative pathways for long-term sustainability with a focus on the grassland ecosystems in the ADB region. Our overarching goal is to better understand the socio-ecological processes, drivers, responses, and sustainability issues of grassland ecosystems in the ADB.

\section{Socio-ecology of the Asian Dryland Belt}

The ADB is dominated by grasslands, with an arid and semi-arid climate (Chuluun and Ojima 2002; Ojima and Chuluun 2008; Qi and Evered 2008; Lioubimtseva and Henebry 2009; Klein et al. 2012). The geopolitical systems are diverse, but most of countries in the region have either developing or transitioning economies with growing demands for water resources to produce meat and dairy products (De Beurs and Henebry 2004; Ojima and Chuluun 2008; De Beurs et al. 2009; Qi et al. 2012b; Chen et al. 2013, 2015a, 2015b). The soils are generally productive but water resources are very limited and are primarily provided by snow and glacier melts, which prevent the region from being a productive agriculture (Qi and Kulmatov 2008; Groisman et al. 2009; Sommer and de Pauw 2011; Klein et al. 2012).

The traditional lifestyle of the people in the region is nomadic, which spatially and temporally optimizes livestock grazing by adjusting seasonality and spatial variability of forage (Grousset 1970; Reid et al. 2014). However, this tradition has begun to shift in response to a variety of changes in institutions, administrative boundaries, climate variability, urbanization, and economic development (Fernández-Giménez et al. 2012; John et al. 2013; Chen et al. 2015a; Zhang et al. 2017). With economic advances in the region and continued globalization, the demands in the ADB for livestock production have increased (Delgado 2005; Kearney 2010; FAO 2013; Fernández-Giméneza et al. 2017), raising some serious questions regarding long-term sustainability, as the region has scarce water and additional resources for food production.

Another challenge is the expectation for the ADB to produce the required livestock to meet the increasing 
demands for meat and dairy products. Grass-fed livestock uses water, soil, and energy resources very intensively in ADB. Approximately, 400-2500 gallons of water, 1 gallon of gasoline equivalent energy, and 12 pounds of grain are required to produce 1 pound of beef, according to the recent estimate by the EarthSave International group (http://www.earthsave.org/environ ment.htm). The above figures exclude other associated energy/water requirements (e.g., processing, storing, distributing, and cooking) for a meat-based diet (US Department of Agriculture 1989). The inefficiency associated with meat production, processing, transportation, and consumption is counterproductive to water and energy use efficiency in any dryland region (Qi and Kulmatov 2008). For the ADB, producing the necessary amount of livestock does not seem a sustainable pathway.

\section{Current undertaking and issues}

Current approaches in livestock management in the ADB can be summarized in a transition framework of grassland livestock production systems (Fig. 2), where demands and supplies are balanced through economic incentives. The growing internal and external demands for meat are responsible for local actions that increase livestock production, including grasslands to cropping system conversion for animal feedstock, or increasing grazing intensity, or a combination of both. No matter which action one takes, sustainability challenges arise because of the state of the food, water, climate, and land nexus in the region (de Beurs and Henebry 2004; de Beurs et al. 2009; Qi and Evered 2008; Qi et al. 2012b; Wright et al. 2012; Chen et al. 2013, 2015b).

The first alternative approach is to use the landless systems (i.e., concentrated animal feeding operation
(CAFO)), which house grain-fed livestock and move animals off pastoral lands. Massive and intensive livestock production answers the rapidly increasing demands for meat by using synthesized feedstock from croplands. A disadvantage, however, is the waste from CAFOs and its associated environmental impacts (e.g., emissions of methane and other greenhouse gases, increased air and water pollutions, and loss of soil carbon) (Lal 2011). Another indirect impact from intensified and/or expanded cropping systems is the extensive cultivation of marginal pastoral lands in the ADB. Based on the analysis of land use and land cover change, there has been a significant amount of grasslands and shrublands converted to feedstock croplands, presumably for CAFO livestock operations (Table 1). Geographically, these conversions occurred around or near major cities where urbanization promoted meat consumption, as much of the peri-urban grasslands converted to croplands. This can be seen in the positive vegetation growth from satellite images of cities and major development zones in the region (Klein et al. 2012) (Fig. 3). The areas with elevated NDVI (normalized difference vegetation index) are cropland, of which some are converted from grasslands and likely included irrigation systems and intensive fertilization (Wright et al. 2012; Emam et al. 2015).

This approach is being challenged by the amount of sustainable water resources for crops and environmental degradation (e.g., increased soil salinity, lowered ground water, reduced soil carbon). It also creates a competition for water between livelihoods and ecosystem services (e.g., residential water uses, recharge of Aral Sea, increased surface irrigation, maintenance of acceptable stream flows at lower streams). Increased irrigation will result in significantly higher evapotranspiration (ET) and

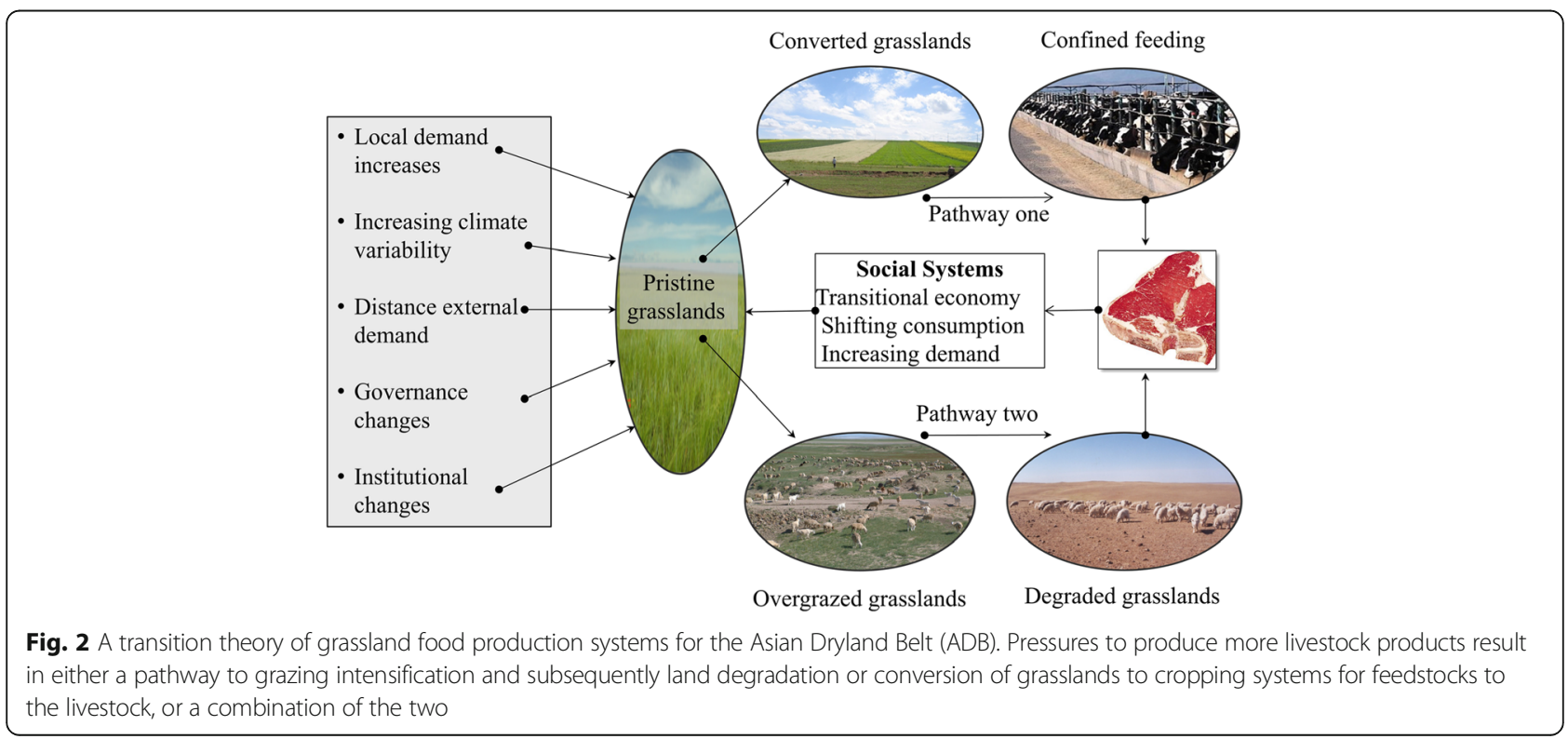


Table 1 Transformation matrix $\left(\mathrm{km}^{2}\right)$ of land cover/use in the Asian Dryland Belt (ADB) from 2001 (columns) to 2012 (rows)

\begin{tabular}{|c|c|c|c|c|c|c|c|c|c|c|c|c|}
\hline & Forests & Shrubland & Savanna & Grassland & Wetland & Cropland & Urban & Crop & Snow & Barren & Water & Total \\
\hline Forests & 141,711 & 486 & 7042 & 14,294 & 558 & 1252 & 0 & 5111 & 143 & 726 & 855 & 172,178 \\
\hline Shrubland & 4558 & 275,502 & 1708 & 221,564 & 119 & 20,169 & 0 & 965 & 1221 & 54,707 & 294 & 580,807 \\
\hline Savanna & 44,072 & 1285 & 10,546 & 28,011 & 650 & 2806 & 0 & 5316 & 311 & 856 & 571 & 94,424 \\
\hline Grassland & 28,314 & 130,965 & 7004 & $5,235,299$ & 1586 & 154,614 & 0 & 24,809 & 10,557 & 150,616 & 4467 & $5,748,231$ \\
\hline Wetland & 256 & 23 & 76 & 525 & 490 & 84 & 1 & 79 & 27 & 85 & 211 & 1857 \\
\hline Cropland & 4897 & 5910 & 1732 & 254,849 & 357 & 287,885 & 0 & 21,198 & 18 & 669 & 218 & 577,733 \\
\hline Urban & 0 & 0 & 0 & 0 & 1 & 28,346 & 0 & 0 & 0 & 0 & 0 & 28,347 \\
\hline Crop & 16,270 & 529 & 3934 & 31,605 & 711 & 19,339 & 0 & 31,898 & 22 & 237 & 190 & 104,735 \\
\hline Snow & 88 & 81 & 13 & 16,152 & 26 & 83 & 0 & 6 & 68,436 & 3156 & 325 & 88,366 \\
\hline Barren & 1156 & 151,710 & 146 & 439,807 & 194 & 6959 & 0 & 34 & 26,972 & $3,097,249$ & 5306 & $3,739,533$ \\
\hline Water & 1353 & 85 & 189 & 3931 & 369 & 227 & 1 & 61 & 1398 & 14,571 & 109,786 & 131,971 \\
\hline Total & 242,675 & 566,576 & 32,390 & $6,246,037$ & 5061 & 493,418 & 28,348 & 89,477 & 109,105 & $3,322,872$ & 12,223 & $9,287,148$ \\
\hline
\end{tabular}

The land cover/use data was obtained from the MODIS-derived MCD 12Q1 (https://lpdaac.usgs.gov/dataset_discovery/modis/modis_products_table/mcd12q1)

leftover salt in the soil (Kulmatov 2008). Irrigation and cropping practices in the Amu Darya basin, for example, have complicated cropping practices. During 1990-2010, winter wheat production has increased in response to food security concerns (Aldaya et al. 2010), with wheat production exceeded cotton production by $95-110 \%$ in terms of acreage sown. In addition, water requirements for cotton $\left(9000 \mathrm{~m}^{3} / \mathrm{ha}\right)$ are now significantly higher compared to winter wheat $\left(5400 \mathrm{~m}^{3} / \mathrm{ha}\right)$, which can be explained by differences in planting calendars. Cotton grows during the warm summer when there is a water deficit, whereas winter wheat is planted in fall and harvested in spring (Conrad et al. 2013). Before the formation of the Central Asian republics, for example, water allocation and irrigation systems were well maintained and heavily subsidized. However, the dissolution of the Soviet Union in 1991 saw the collapse of state support and a transition toward market economy, under which the local farmers have to fend for themselves (Rakhmatullaev et al. 2010). The prolonged drought of 1998-2001 led many private farmers to obtain deeper ground water by drilling bore holes - an unsustainable practice for the region's long run (Kulmatov 2008; Lemaire et al. 2014; Madani 2014; Emam et al. 2015).

This approach also has morally challenged the classical school of thought: do not feed animals food that could be eaten by humans (Eisler et al. 2014). In addition to the mounting pressures to convert pastoral lands to agricultural croplands, this approach also requires additional water and energy resources that could otherwise improve the livelihoods of local communities. Worse yet, environmental pollution from animal waste and agricultural intensification for livestock are clearly not avoidable for the ADB because of the poor soils and water scarcity in these marginal pastoral lands (Chuluun and Ojima 2002; Kulmatov 2008; Qi and Kulmatov 2008).
The second approach intensifies grazing by increasing the animal population beyond what the grasslands can sustainably support. This practice not only may initially increase meat production but also may cause long-term degradation of pastoral lands. It was estimated that more than $60 \%$ of the world's rangelands have been damaged by overgrazing during the past half century (Repetto 1989; Reynolds et al. 2007). Within the ADB, rangeland degradation in Central Asian countries were estimated to be $13.2 \%$ in Kazakhstan, $42 \%$ in Uzbekistan, $50 \%$ in Turkmenistan, 74\% of Kyrgyzstan, and 90\% Tajikistan (Mirzabaev et al. 2016). Our independent estimates based on remote sensing technology, for degradations are $15 \%$ in Tajikistan and $38 \%$ in Kyrgyzstan and Kazakhstan. Note that these may underestimate the degradation severity because not only does the percentage of vegetation cover matter but also the changes in species composition, which is critical for providing ecosystem services (De Beurs and Henebry 2004; Qi and Evered 2008; De Beurs et al. 2009; Qi et al. 2012a, 2012b; Chen et al. 2013).

As a proxy for forage production, NDVI during 19802015 in the ADB suggests that there was a significant reduction in forage across the entire region (Fig. 3a). It appears that the mean annual forage growth has been decreasing across the region, suggesting a declining grazing capacity.

The third approach is to use supplementary feedstock from cropping systems. This approach takes advantage of the animal's ability to consume plants unsuitable for human diets that grow on cultivated land, which require significant human intervention (aka marginal lands). Supplemental feeding is provided only when needed, maximizing forage use efficiency while minimizing the pressure and reliance on feedstock. In theory, the concept is ideal, but the 

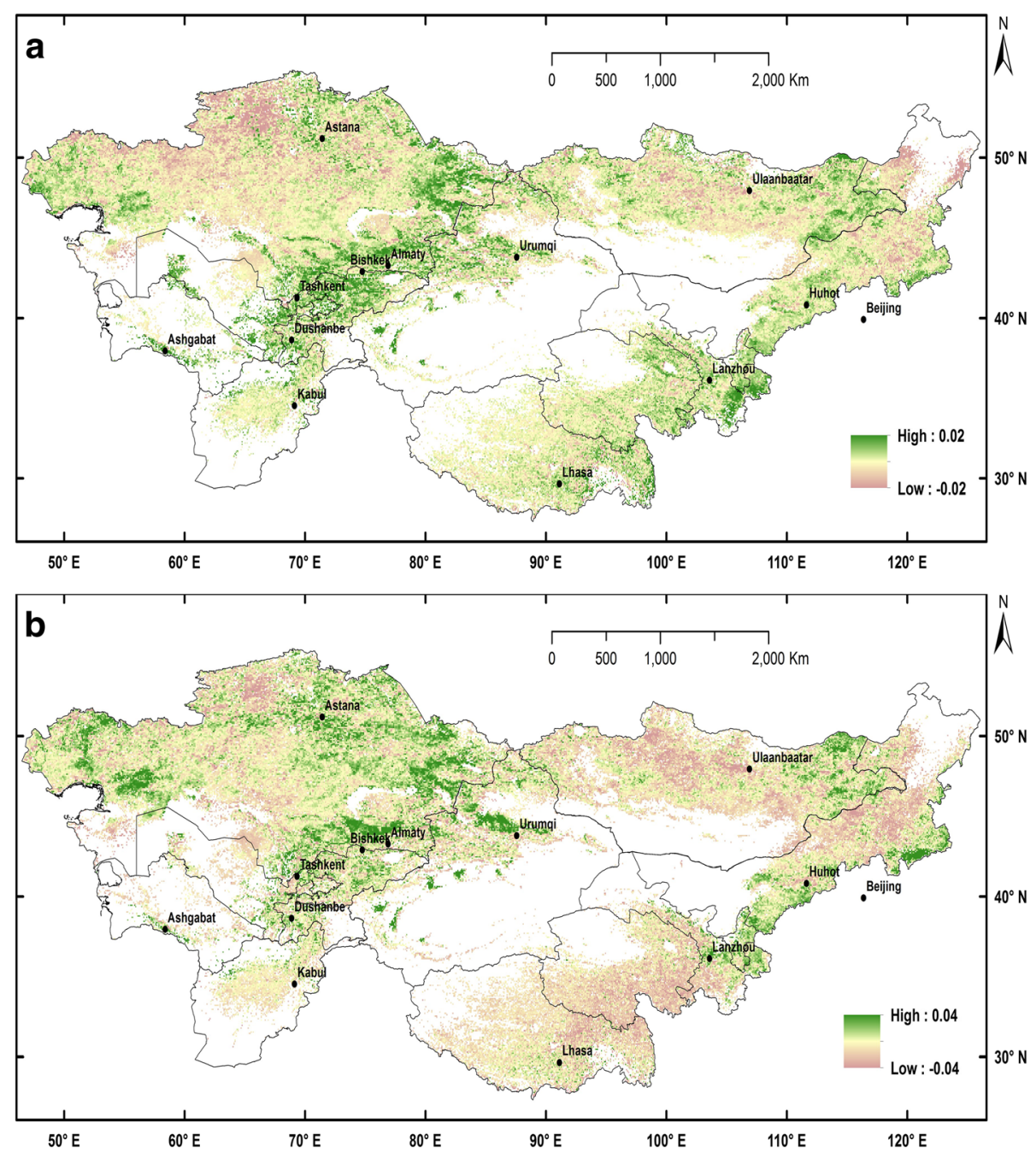

Fig. 3 The changes in forage proxies (or total amount of green biomass) during 1981-2013 based on Advanced Very High Resolution Radiometer (AVHRR) satellites. $\mathbf{a}$ is the trend of mean NDVI (Normalized Difference Vegetation Index), which may indicate forage, whereas $\mathbf{b}$ is the change in maximum NDVI over time

challenge is in the balance, which prevents overgrazing while maximizing foraging.

\section{Grand challenges in sustainable livestock production for the ADB}

Grazing in the ADB seems to have already reached its maximum capacity and spread its degraded grasslands, suggesting a need to reduce grazing intensity across the region (Reid et al. 2014; John et al. 2016; Gao et al. 2016). As a result, meat production defaults to CAFO, which will unlikely be sustained through grain-based feedstock due to the limited amount of croplands and fresh water resource in the region. A major challenge is as follows: How can more sustainable feedstock be produced to support livestock production where there are regional physical and ecological constraints? Sound solutions for this challenge require a comprehensive understanding of the nexus of water, land, food, and society because any single approach will result in bias and unsustainability (Brazilian et al. 2011; Granit et al. 2012; Stucki and Sojamo 2012; FAO 2014; Flammini et al. 2014).

Increasing climate variability adds challenges to grassland ecosystems to produce animal feed. With the increased frequency and magnitude of extreme climate events (e.g., droughts, $d z u d s$, and dust storms) in the region (Chen et al. 2013), it is expected that livestock production will be further reduced, leading to-in theory-a livestock decline (Lioubimtseva and Henebry 2009; Fernández-Giménez et al. 2012; Reid et al. 2014) while meat price will continue to rise. Finally, it is also important to consider the instability of institutions, policies, and governance (e.g., land tenure, ownership, leasing policy) that can have significant impact on long-term investments or sustainability 
strategies (Fernández-Giménez 2002; Chen et al. 2015b; Zhang et al. 2017).

Current approaches and future trajectories to enhance livestock production are single-minded (i.e., feeding animals with cropland-based grains or overgrazing for short-term benefits) because they will contribute to long-term degradation. There is an urgent need to develop and implement a sound sustainable management framework in order to produce the needed meat without degrading the environment or depriving other ecosystem services.

\section{A WEF nexus framework for sustainable pathways}

The grassland ecosystems in the ADB are complex and constrained by available water and energy for sustainable livestock production. A system approach for the future should be holistically constructed through examining the nexus of water, energy, and food (WEF) systems (Granit et al. 2012; Qi 2015). The concept of WEF nexus recently emerged in recent years (Vosti and Reardon 1997; Hoff 2011; Granit et al. 2012; Stucki and Sojamo 2012; Bhaduri et al. 2015) and is deemed to be an appropriate framework to address the grand challenges faced by grassland ecosystems in the ADB (Qi 2015; Kurian 2017). Here, a grassland ecosystem WEF nexus framework (Fig. 4) specifically considers the interactive nature of the water, energy, and food systems within a consumption culture. The framework treats the grassland ecosystem as the nexus where grazing livestock requires water to produce forage, while energy is used to produce the fertilizers needed for feedstock and livestock production (Qi 2015). Our framework and five specific proposals listed below are based on the reviews and analyses of previous work, focusing on a sustainable pathway to meet the increasing demand for livestock production while protecting grassland ecosystems in the ADB:

1. Spatially optimize grazing across the heterogeneous grasslands to account for the uneven distribution of water resources and rainfall variability and for energy conservation caused by reduced long-distance feed transport. Over the past three decades, land privatization in the ADB has occurred in the form of "right to use", with ownership or lease/rent belonging to individual families. Due to the high spatial variations in soil, water, and accessibility, the nomadic grazing lifestyle is ideal but impossible to continue due to the administrative boundaries that divide and fragment the grazing landscape (Chen et al. 2015b; Zhang et al. 2017). Therefore, with this finite amount of water resources, families in less economically developed areas may have no choice but continue degrading the grasslands or convert them to cultivated lands in order to meet the surviving needs. It also suggests that individual

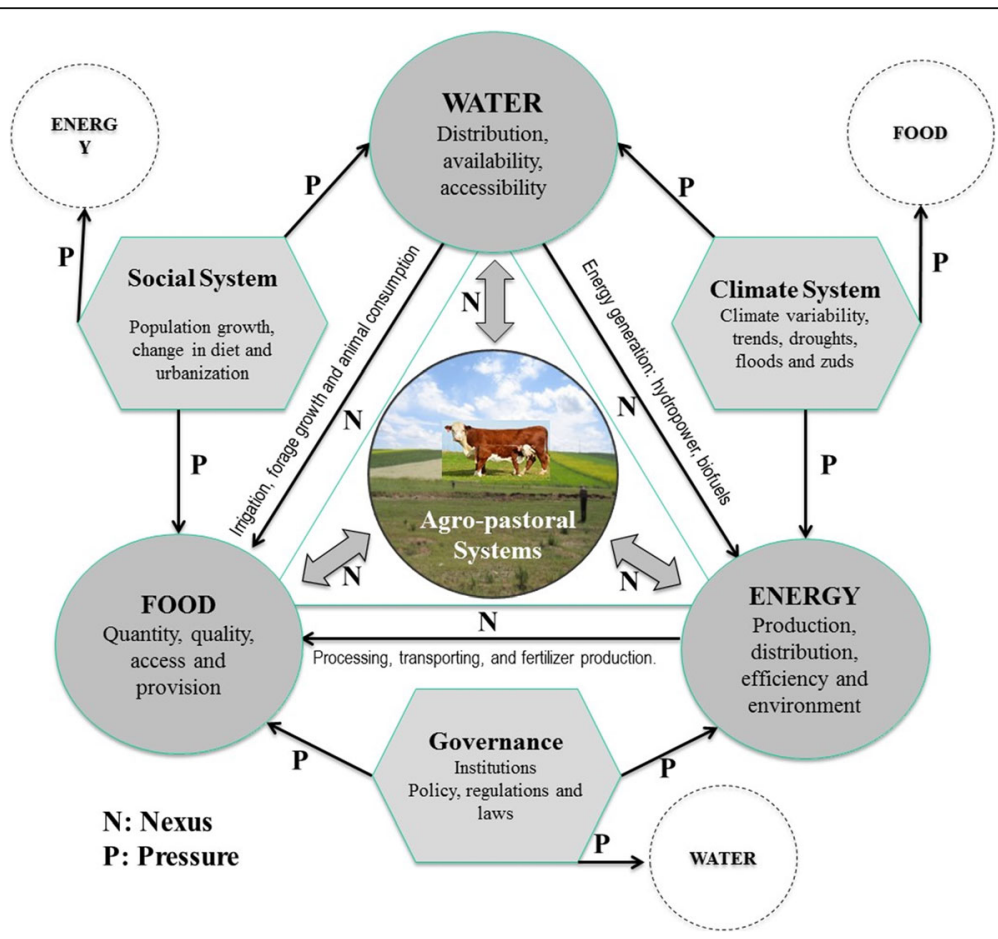

Fig. 4 Agro-pastoral lands are at the center of the nexus of food, energy, and water under increasing climate impacts, human pressures (e.g., land use intensity, cover change), and changing institutions 
herders, owners, and communities in these areas should consider community-based cooperation to spatially optimize resources for grazing-addressing the challenges that arise from administrative boundaries and constraints. Cooperative community-based grazing might alleviate these challenges, thus optimizing water and soil resource use efficiency. By doing so, the cost for feedstock (e.g., hay) transportation can be reduced while the likelihood of overgrazing is minimized.

2. Balance grazing with supplemental feedstock to maximize livestock production and efficiently harvest photosynthesis. Seasonal grass phenology can and should be synchronized with supplementary feedstock (i.e., grain or hay) by taking advantage of forage in the growing season and storing feedstock to ensure yearlong production. This way, forage can be effectively used by livestock during the growing season and supplemental feeding can be used during the nongrowing season. At the same time, pressure to convert grasslands for feedstock can be reduced, which subsequently reduces the energy use associated with fertilizer production as well as irrigation for intensive cropping. The challenge of this approach is to determine an optimal balance between grazing and supplementary feedstock use, which presumably depends on resource availability in different seasons. Numerous studies have shown that moderate grazing intensity can not only produce livestock but also promote species diversity and the ecological integrity of grassland ecosystems. Therefore, an optimal balance could achieve both environmental conservation and livestock production (e.g., Shao et al. 2014; Han et al. 2016).

3. Promote ecological restorations of marginal grasslands to enhance photosynthesis through seeding grasses and soil remediation. Previous research indicated that overgrazing would lead to fast and visible degradation that can be restored in a short period of time if native grasses are applied. Degradation from long-term and high-frequency hay harvests without input over a long time period might be difficult to restore because the loss of soil nutrients, top soils, and seed banks. Restoring degraded and marginal lands with limited human intervention is highly recommended to alleviate grazing pressures in grassland ecosystems across the ADB.

4. Manage water effectively to maximize water use efficiency for food production. It is important to use water resources efficiently. The ADB is one of the world's largest water-acre areas, where much of the arable cropland relies on irrigation. With the continuous warming trend (i.e., high temperature and high evapotranspiration loss) and lowering ground water tables, there exist few options to extract water for higher forage production. Diversion of surface water for grassland improvements may benefit long-term growth of grasslands. Some techniques exist and may be adopted for restoration, including diking, land smoothing, terracing, and indentations for water use efficiency and soil conservation (Unger and Agassi 1995; Ventura et al. 2003).

5. Change consumption behaviors to optimize meat intake. By the time households rise above the poverty line, most would have already completed a shift from a cereal-based to a meat-based diet (Randolph et al. 2007; Tschirley et al. 2015). However, the right balance between meat consumption and nutritional needs must be maintained for a healthy lifestyle. From a water, energy, and food nexus perspective, meat production requires substantially higher water and energy, suggesting that socioeconomic means and incentives need to be in place to increase awareness and promote alternative diets.

\section{Discussion}

The proposed pathways toward a sustainable grassland ecosystem for the ADB are only a part of the solution. Critical challenges remain and need further sound and applicable solutions to maintain sustainable ecosystems. The following four specific aspects of the WEF nexus challenges need additional attention:

\section{Achieve an agreeable balance of trade-offs among} different ecosystem services. We have focused primarily on the provisional ecosystem service-forage and subsequently livestock production - provided by grassland ecosystems. Maximizing provisional ecosystem services is often at the cost of other ecosystem services, such as biodiversity, water flux, carbon sequestration, and environmental integrity. The greatest challenge in balancing these multiple ecosystem services lies in our inability to quantify the values associated with different ecosystem services and their spatiotemporal changes. One often finds that a particularly valuable ecosystem service is priceless for one community but not for another when distance is considered (Wan et al. 2017). However, this perceived tragedy of the commons should be, and can be, minimized through community negotiation and environmental integrity. One option to such a pathway is to optimize rather than maximize provisional services through a trade-off of water and energy.

2. Balance long- and short-term benefits. To survive and thrive is human nature. Our effort to improve our quality of life and overall sustainability is based on the premise that humans will survive with essential 
food and water resources. When a society, especially a rapidly growing society, reaches the point where the consumption exceeds the capacity that ecosystems can regenerate, it collapses (Motesharrei et al. 2014). Many contemporary societies maximize consumption for immediate or short-term benefits to livelihood, often at a rate that jeopardizes long-term benefits and sustainability. A large gap exists between developing and developed countries in regard to the consumption of dairy and meat products, with the latter requiring as much as nine times the water and energy to produce $1 \mathrm{~kg}$ of beef compared to cereal. Converting marginal grasslands into croplands for livestock feed is a convenient and fast way to utilize ecosystem services for short-term, economic prosperity and leads to ecosystem degradation. These practices can result in a situation where recovery is either physically impossible or financially incapable (e.g., Gelfand et al. 2011). More significant emphasis should be placed on long-term sustainability, with strategies and policies that balance short- and long-term benefits.

3. Bend the trajectory of consumption behaviors and culture. Over the last century, there has been a significant increase in food production resulting from agricultural intensification and technological advances in breeding. At the same time, a major increase in consumption (quantity) and shift in dietary behavior (quality) have occurred. Meat consumption is a global phenomenon that resulted in about $70 \%$ of crops being fed to livestock that could have fed about 4 billion people alternatively. If the global demand for meat continues, the pressure on grasslands will also be escalated because of the cumulative effects over time. The challenge is to achieve the right balance between conservative diet behavior and nutritional needs from meat consumption in order to ensure a sustainable society. Here, human health and the ecological health of an ecosystem are tightly coupled and need to be addressed together.

4. Community participation, adaptation, and coordination. There is a lack of citizen science that engages, incentivizes, and promotes community participation in the development and implementation of sustainable solutions. While the concept of codesigning and co-developing sustainable pathways is sound, its implementations require active participation of citizens and stakeholders at all scales. This is particularly important when trade-offs between local and distant communities are concerned. Although food security is a global problem, it requires local solutions and coordination across communities both near and far in order to avoid any potential conflict. A solution in one location may result in an unintended problem for a distant community. A typical example is hydro-dam construction. It increases irrigation capacity for a local community but also alters the river system downstream, causing water resource shortages or unsynchronized water for crops. Thus, developing and implementing space-based solutions at the local community level is another challenging issue to be addressed.

\section{Conclusions}

Current practices to enhance livestock production are clearly unsustainable. To bend the current unsustainable trajectory of grassland intensification, alternative pathways must be developed. Any sound sustainable pathway should consider significantly increasing the output from the same area of land while simultaneously limiting environmental impacts with well-balanced water and energy sectors. This includes using less water and energy and reducing waste, greenhouse gas emissions, and contamination of watercourses while producing the needed forage for livestock. A sound, applicable, and sustainable intensification strategy should increase both production and environmental quality. As to the extent of intensification, clear trajectories should be set by the developmental goals of the local communities and restrained by their available natural resources, such as water quality and soil nutrients. Meeting the demand in grassland for livestock production cannot be addressed without considering the nexus of food, water, energy, and climate. Future innovations in system approach and technology are needed to balance the trade-offs among ecosystem services for long-term sustainability.

\footnotetext{
Acknowledgements

This study was supported by the NSF Belmont forum (1531086), the National Aeronautics and Space Administration Land Cover Land Use Change program (NASA LCLUC) (\#NNX15AD51G), the Monsoon Integrated Regional Studies, with funding from USDA through AgBioResearch (\#MICL02264) at Michigan State University, and the "Dynamics of Coupled Natural and Human Systems (CNH)" Program of the NSF (\#1313761). We thank Gabriela Shirkey for editing the language and format of the manuscript.
}

Authors' contributions

All authors contributed to the framework, reviews, and discussions on the recommendations for sustainable pathways. RJ performed the image processing; JQ led the writing, with inputs from all other authors. All authors read and approved the final manuscript.

\footnotetext{
Authors' information

Jiaguo Qi (JQ) is a Professor of Geography, Environment and Spatial Sciences and Director of the Center for Global Change \& Earth Observations at Michigan State University. He is also affiliated with Zhejiang University, China. He is primarily interested in broad scale global change and its implications to water, energy, and food systems, with a focus on agricultural and grassland ecosystems. Xiaoping Xin (XX) is a Research Scientist at the Chinese Academy of Agricultural Sciences, China, with extensive expertise in remote sensing, grassland ecosystem processes, and management practices using in-situ and remote data and information. Ranjeet John (RJ) is a Research Associate at the Center for Global Change \& Earth Observations, Michigan State University, whose expertise includes technical remote sensing imagery analysis, land use and land cover change, and its ecological implications. Pavel Groisman,
} 
hydrological scientist at the University Corp. for Atmospheric Research, has expertise in large-scale processes of atmospheric circulation and its impacts on Northern Eurasia ecosystems. Jiquan Chen (JC), Professor of Geography, Environment, and Spatial Sciences and the Center for Global Change \& Earth Observations at Michigan State University, is a landscape ecologist with extensive expertise in landscape processes, carbon science, and remote sensing.

\section{Competing interests}

The authors declare that they have no competing interests.

\section{Publisher's Note}

Springer Nature remains neutral with regard to jurisdictional claims in published maps and institutional affiliations.

\section{Author details}

'Department of Geography, Environment, and Spatial Sciences and Center for Global Change and Earth Observations, Michigan State University, East Lansing, MI, USA. ${ }^{2}$ Chinese Academy of Agricultural Sciences, Beijing, China. ${ }^{3}$ University Corp. for Atmospheric Research NOAA National Centers for Environmental Information, Asheville, NC, USA. ${ }^{4}$ Zhejiang University, Hangzhou, China.

Received: 10 January 2017 Accepted: 19 May 2017

Published online: 13 June 2017

\section{References}

Aldaya MM, Muñoz G, Hoekstra AY (2010) Water footprint of cotton, wheat and rice production in Central Asia. Delft: UNESCO-HHE Institute for Water Education. Value of Water Research Report Series, no. 41

Alexandratos N, Bruinsma J (2012) World agriculture towards 2030/2050, ESA Working Paper No. 12-03., http://www.fao.org/docrep/016/ap106e/ap106e.pdf

Bhaduri A, Ringler C, Dombrowski I, Mohtar R, Scheumann W (2015) Sustainability in the water-energy-food nexus. Water Int 40:723-732

Bosire CK, Ogutu JO, Said MY, Krol MS, Leeuw JD, Hoekstra AY (2015) Trends and spatial variation in water and land footprints of meat and milk production systems in Kenya. Agric Ecosyst Environ 205:36-47

Bosire CK, Lannerstad M, de Leeuw J, Krol OMS, Ochungo JO, Leeuw PA, Hoekstra AY (2017) Urban consumption of meat and milk and its green and blue water footprints-patterns in the 1980s and 2000s for Nairobi, Kenya. Sci Total Environ 579:786-796

Brazilian M, Rogner H, Howells M, Hermann S, Arent D, Gielen D, Yumkella KK (2011) Considering the energy, water and food nexus: towards an integrated modelling approach. Energy Policy 39(12):7896-7906

Chen J, Wan S, Henebry G, Qi J, Gutman G, Sun G, Kappas M (eds) (2013) Dryland East Asia (DEA): land dynamics amid social and climate change. HEP and De Gruyter, Berlin

Chen J, John JR, Shao C, Fan Y, Zhang Y, Amarjargalj A, Brown D, Qi J, Han J, Lafortezza R, Dong G (2015a) Policy shifts influence the functional changes of the CNH systems on the Mongolian Plateau. Environ Res Lett 10:085003

Chen J, John R, Zhang Y, Shao C, Brown DG, Batkhishig O, Amarjargal A, Ouyang Z, Dong G, Wang D, Qi I (2015b) Divergences of two coupled human and natural systems on the Mongolian Plateau. Bioscience 65:559-570

Chuluun T, Ojima D (2002) Land use change and carbon cycle in arid and semiarid lands of East and Central Asia. Sci China Ser C Life Sci-Eng Ed 45:48-54

Conrad C, Rahmann M, Machwitz M, Stulina G, Paeth H, Dech S (2013) Satellite based calculation of spatially distributed crop water requirements for cotton and wheat cultivation in Fergana Valley, Uzbekistan. Glob Planet Chang 110: 88-98

De Beurs KM, Henebry GM (2004) Land surface phenology, climatic variation, and institutional change: analyzing agricultural land cover change in Kazakhstan. Remote Sens Environ 89:497-509

De Beurs KM, Wright CK, Henebry GM (2009) Dual scale trend analysis for evaluating climatic and anthropogenic effects on the vegetated land surface in Russia and Kazakhstan. Environ Res Lett 4:045012

Delgado C (2003) Rising consumption of meat and milk in developing countries has created a new food revolution. J Nutr 133:3907S-3910S

Delgado C (2005) Rising demand for meat and milk in developing countries: implications for grasslands-based livestock production. A Global Resource, Grassland, pp 29-39
Eisler MC, Lee MRF, Tarlton JF, Martin GB, Beddington J, Dungait JAJ, Greathead H, Liu J, Matthew S, Miller H, Misselbrook T, Murry P, Vinod VK, Van Saun R, Winter M (2014) Steps to sustainable livestock. Nature 507:32-34

Emam AR, Kappas M, Akhavan S, Hosseini SZ, Abbaspour KC (2015) Estimation of groundwater recharge and its relation to land degradation: case study of a semi-arid river basin in Iran. Environ Earth Sci 74(9):6791-6803

FAO (2009) How to feed the world 2050., http://www.fao.org/wsfs/forum2050/ wsfs-forum/en/. Accessed 9 Jan 2017

FAO (2013) Statistical yearbook. FAO, Rome

FAO (2014) The water-energy-food nexus: a new approach in support of food security and sustainable agriculture. Food and Agriculture Organization of the United Nations, Rome

Fernández-Giménez ME (2002) Spatial and social boundaries and the paradox of pastoral land tenure: a case study from postsocialist Mongolia. Hum Ecol 30:49-78

Fernández-Giménez ME, Batkhishig B, Batbuyan B (2012) Cross-boundary and cross-level dynamics increase vulnerability to severe winter disasters (dzud) in Mongolia. Glob Environ Chang 22:836-851

Fernández-Giméneza ME, Venable NH, Angerer J, Fassnacht SR, Reidb RS, Khishigbayar RS (2017) Exploring linked ecological and cultural tipping points in Mongolia. Anthropocene 17:46-69

Flammini A, Puri M, Pluschke L, Dubois O (2014) Walking the nexus talk: assessing the water-energy-food nexus in the context of the sustainable energy for all initiative. Food and Agriculture Organization of the United Nations, Rome

Gao L, Kinnucan H, Zhang Y, Qiao G (2016) The effects of a subsidy for grassland protection on livestock numbers, grazing intensity, and herders' income in Inner Mongolia. Land Use Policy 54:302-312

Gelfand I, Zenone T, Jasrotia P, Chen J, Hamilton SK, Robertson GP (2011) Carbon debt of Conservation Reserve Program (CRP) grasslands converted to bioenergy production. PNAS 108(33):13864-13869

Gerbens-Leenes PW, Nonhebel S, Krola MS (2010) Food consumption patterns and economic growth. Increasing affluence and the use of natural resources. Appetite 55(3):597-608

Godfray HCJ, Beddington JR, Crute IR, Haddad L, Lawrence D, Muir JF, Pretty J, Robinson S, Thomas SM, Toulmin C (2010) Food security: the challenge of feeding 9 billion people. Science 327(5967):812-818

Granit J, Jägerskog A, Lindström A, Björklund G, Bullock A, Löfgren R, Pettigrew S (2012) Regional options for addressing the water, energy and food nexus in Central Asia and the Aral Sea Basin. Int J of Water Res Dev 28(3):419-432

Groisman PY, Clark EA, Kattsov VM, Lettenmaierb DP, Sokolik IN, Aizen VB, Cartus O, Chen J, Conrad S, Katzenberger J, Krankina O, Kukkonen J, Machida T, Maksutov S, Ojima D, Qi J, Romanovsky VE, Sanotoro M, Schmullius CC, Shiklomanov Al, Shimoyama K, Shugart HH, Shuman JK, Sofiev MA, Sukhinin AL, Vörösmarty C, Walker D, Wood EF (2009) The Northern Eurasia Earth Science Partnership: an example of science applied to societal needs. Bull Am Meteorol Soc 90:671-688

Grousset R (1970) The empire of the steppes: a history of Central Asia. New Brunswick (NJ): Rutgers University Press; 1970.

Han J, Li L, Chu H, Miao H, Chen S, Chen J (2016) The effects of grazing and watering on ecosystem $\mathrm{CO} 2$ fluxes vary by community phenology. Environ Res 144:64-71

Hoff H (2011) Understanding the nexus: background paper for the Bonn2011 Nexus Conference. IEA. (2012). World Energy Outlook, Int Energy Agency, Paris

John R, Chen J, Ou-yang ZT, Xiao J, Becker R, Samantha A, Ganguly S, Yuan W, Batkhishig O (2013) Vegetation response to extreme climate events on the Mongolian Plateau from 2000 to 2010. Environ Res Lett 8:035033

John R, Chen J, Kim Y, Ou-yang ZT, Xiao J, Park H, Shao C, Zhang Y, Amarjargal A, Batkhshig O, Qi J (2016) Differentiating anthropogenic modification and precipitation-driven change on vegetation productivity on the Mongolian Plateau. Landsc Ecol 31:547-566

Kearney J (2010) Food consumption trends and drivers. Phil Trans R Soc B 365: 2793-2807

Klein I, Gessner U, Kuenzer C (2012) Regional land cover mapping and change detection in Central Asia using MODIS time-series. Appl Geogr 35:219-234

Kulmatov R (2008) Modern problems of using, protection and management of water and land resources of the Aral Sea basin. Environmental problems of Central Asia and their Economic, Social and Security Impacts. Collection of Articles, Springer, 2008, pp.24-32

Kurian M (2017) The water-energy-food nexus- trade-offs, thresholds and transdisciplinary approaches to sustainable development. J Environ Sci Policy 68:97-106

Lal R (2011) Reducing emissions and sequestering carbon in agroecosystems. Food Policy 36:S33-\$39 
Lemaire G, Franzluebbers A, de Faccio CPC, Dedieu B (2014) Integrated croplivestock systems: strategies to achieve synergy between agricultural production and environmental quality. Agric Ecosys Environ 190:4-8

Lioubimtseva E, Henebry GM (2009) Climate and environmental change in arid Central Asia: impacts, vulnerability, and adaptations. J Arid Environ 73:963-977

Madani K (2014) Water management in Iran: what is causing the looming crisis? J Environ Stud 4:315-328

McMichael AJ, Powles JW, Butler CD, Uauy R (2007) Food, livestock production, energy, climate change, and health. Lancet 370(9594):1253-1263

Mirzabaev A, Ahmed M, Werner J, Pender J, Louhaichi M (2016) Rangelands of Central Asia: challenges and opportunities. J Arid Land 8:93-108

Motesharrei S, Rivas J, Kalnay E (2014) Human and nature dynamics (HANDY): modeling inequality and use of resources in the collapse or sustainability of societies. Ecol Econ 101:90-102

Ndambi OA, Hemme T, Latacz-Lohmann U (2007) Dairying in Africa-status and recent developments. Livest Res Rural Dev 19(3):111

Ojima D, Chuluun T (2008) Policy changes in Mongolia: implications for land use and landscapes. In Fragmentation in semi-arid and arid landscapes; Springer Netherlands, pp. 179-193.

Qi J (2015) Challenges and alternatives to sustainable management of agriculture and pastoral ecosystems in Asian Drylands. Abstract of 2015 AGU Fall Meeting, Moscone Center, San Francisco

Qi J, Evered KT (eds) (2008) Environmental problems of Central Asia and their economic, social and security impacts. Springer Science \& Business Media

Qi J, Kulmatov R (2008) An overview of environmental issues in Central Asia. Qi J, Evered K (eds) (2008) Environmental problems of Central Asia and their economic, social and security impacts. Springer Press

Qi J, Bobushev T, Kulmatov R, Groisman P, Gutman G (2012a) Addressing globa change challenges for Central Asian socio-ecosystems. Front Earth Sci 6:115-121

Qi J, Chen J, Wan S, Henebry G, Brown D (2012b) Understanding the coupled natural and human systems in the Dryland East Asia. Environ Res Lett 7: 015202

Rakhmatullaev S, Huneau F, Kazbekov J, Le Coustumer P, Jumanov J, El Oifi B, Motelica-Heino M, Hrkal Z (2010) Groundwater resources use and management in the Amu Darya River Basin (Central Asia). Environ Earth Sci 59:1183-1193

Randolph TF, Schelling E, Grace D, Nicholson CF, Leroy JL, Cole DC, Ruel M (2007) Role of livestock in human nutrition and health for poverty reduction in developing countries. J Animal Sci 85(11):2788-2800

Rask KJ, Rask N (2011) Economic development and food production-consumption balance: a growing global challenge. Food Policy 36:186-196

Reid RS, Fernández-Giménez ME, Galvin KA (2014) Dynamics and resilience of rangelands and pastoral peoples around the globe. Annu Rev Env Resour 39 217-242

Repetto R (1989) Renewable resources and population growth: past experiences and future prospects. Popul Environ 10(4):221-236

Reynolds JF, Smith DMS, Lambin EF, Turner BL, Mortimore M, Batterbury SPJ, Downing TE, Dowlatabadi H, Fernández-Giménez ME, Herrick JE, HuberSannwald E, Jiang H, Leemans R, Lynam T, Maestre FT, Ayarza M, Walker B (2007) Global desertification: building a science for dryland development. Science 316:847-851

Robinson TP, Pozzi F(2011) Mapping supply and demand for animal-source foods to 2030. In: Animal Production and Health Working Paper. FAO. Available via DIALOG. http://www.fao.org/docrep/014/i2425e/i2425e00.pdf. Accessed 10 Jan 2017

Sahadeo J, Zanca R (eds) (2007) Everyday life in Central Asia: past and present. Indiana University Press, Indiana

Sans P, Combris P (2015) World meat consumption patterns: an overview of the last fifty years (1961-2011). Meat Sci 109:106-111

Shao C, Li L, Dong G, Chen J (2014) Spatial variation of net radiation and its contribution to energy balance closure in grassland ecosystems. Ecol Process 3:7

Sommer R, de Pauw E (2011) Organic carbon in soils of Central Asia-status quo and potentials for sequestration. Plant Soil 338(1-2):273-288

Stucki V, Sojamo S (2012) Nouns and numbers of the water-energy-security nexus in Central Asia. Int J Water Resources Dev 28(3):399-418

Tilman D, Balzer C, Hill J, Befort BL (2011) Global food demand and the sustainable intensification of agriculture. PNAS 108(50):20260-20264

Tschirley D, Reardon T, Dolislager M, Snyder J (2015) The rise of a middle class in East and Southern Africa: implications for food system transformation. J Int Dev 27(5):628-646

Unger PW, Agassi M (1995) Common soil and water conservation practices. Soil Erosion, Conservation, and Rehabilitation. CRC, Boca Raton, pp 239-266
US Department of Agriculture (1989) Crops: area, yield, production and value. In: US Department of Agriculture (ed) Agricultural statistics. GPO, Washington, DC

Ventura E Jr, Domínguez MA, Norton D, Ward K, López-Bautista M, Tapia-Naranjo A (2003) A new reservoir tillage system for crop production in semiarid areas. ASAE Paper 32315:135-142

Vosti S, Reardon T (eds) (1997) Sustainability, growth, and poverty alleviation: policy and agroecological perspectives. Johns Hopkins University Press, Baltimore

Wan NF, Chen J, Jiang JX, Li B (2017) A conceptual framework for ecosystem management based on tradeoff analysis. Ecol Indic 75:352-361

Wright C, De Beurs KM, Henebry G (2012) Combined analysis of land cover change and NDVI trends in the Northern Eurasian grain belt. Front Earth Sci 6:177-187

Zhang M, Zhang L, Xu Y, Zhang Y, Chen J (2017) Pastureland transfer as a livelihood adaptation strategy for the herdsmen: a case study of Xilingol, Inner Mongolia. Rangeland J doi. doi:10.1071/RJ15121

\section{Submit your manuscript to a SpringerOpen ${ }^{\circ}$ journal and benefit from:}

- Convenient online submission

- Rigorous peer review

- Open access: articles freely available online

- High visibility within the field

- Retaining the copyright to your article

Submit your next manuscript at $\gg$ springeropen.com 